\title{
Analisis Faktor yang Mempengaruhi Continuance Intention pada Penggunaan Mobile Payment dengan Metode Structural Equation Modeling
}

\author{
Regita Ayu Cahyani Zulaikhah ${ }^{1}$, Dr. Mudjahidin, S.T., M.T. ${ }^{2}$, Andre Parvian Aristio, S.Kom., M.Sc. ${ }^{2}$ \\ ${ }^{123}$ Jurusan Sistem Informasi, Fakultas Teknologi Informasi dan Komunikasi, Institut Teknologi Sepuluh \\ Nopember \\ Email: ${ }^{1}$ regita16@mhs.is.its.ac.id, ${ }^{2}$ mudjahidin@is.its.ac.id, ${ }^{3}$ parvian@is.its.ac.id
}

\begin{abstract}
Currently, mobile payment users in Indonesia are increasing from year to year. The presence of this new technology generates different perspectives from men and women. The problem found was finding the effect of the mobile payment platform on continuance intention of the use of mobile payments based on a research model created by Z. Shao, L. Zhang, X. Li dan Y. Guo which has gender moderation variables and perceived risk mediating variables. This study aims to obtain the structural relationship of the influence of the mobile payment platform on the use of mobile payment by considering the influence of gender moderation variables and perceived risk mediating variables based on research model. The analytical method used is Structural Equation Modeling (SEM), where this method is suitable for displaying the correlation of each variable tested. In taking data, questionnaires were given to each of 1000 users with a different gender. From the results of the analysis obtained factors that significantly influence users' trust towards continuance intention of the use of mobile payment in Indonesia, which is a reputation with the value of 8,72 and 4,32 on women and men, respectively. Followed by security with the value of 4,35 and 2,82 on women and men, respectively. It is hoped that this research can provide advice to companies providing mobile payment services in identifying factors to consider the development of mobile payment services in the future.
\end{abstract}

Keywords: Mobile Payment, Continuance Intention, Gender, Structural Equation Modeling

\begin{abstract}
Abstrak. Saat ini, pengguna mobile payment di Indonesia semakin bertambah dari tahun ke tahun. Hadirnya teknologi yang baru ini menghasilkan perspektif yang berbeda dari laki-laki maupun perempuan. Permasalahan yang ditemukan adalah apakah mobile payment platform berpengaruh pada continuance intention terhadap penggunaan layanan mobile payment berdasarkan model riset yang dibuat oleh Z. Shao, L. Zhang, X. Li dan Y. Guo. Berdasarkan model riset terdapat variabel moderasi gender dan variabel mediasi perceived risk. Penelitian ini bertujuan untuk mendapatkan hubungan struktural pengaruh mobile payment platform terhadap penggunaan mobile payment dengan pertimbangan pengaruh variabel moderasi gender dan variabel mediasi perceived risk berdasarkan model riset, mendapatkan cara peningkatan variabel terukur pada model riset, (mobile payment platform, trust in the platform, gender dan perceived risk) yang bisa mempengaruhi penggunaan mobile payment serta mendapatkan variabel lain dalam model riset yang bisa mempengaruhi penggunaan mobile payment. Metode analisis yang digunakan adalah Structural Equation Modeling (SEM), dimana metode ini cocok untuk menampilkan korelasi dari tiap variabel yang diuji. Dalam pengambilan data, kuesioner diberikan kepada 1000 responden dengan gender yang berbeda. Dari hasil analisis diperoleh faktor-faktor yang mempengaruhi kepercayaan pengguna terhadap continuance intention pada layanan mobile payment di Indonesia secara signifikan, yakni reputation dengan nilai 8,72 pada perempuan dan 4,32 pada laki-laki, security dengan nilai 4,35 pada perempuan dan 2,82 pada laki-laki. Diharapkan dengan adanya penelitian ini dapat membantu perusahaan penyedia layanan mobile payment dalam mengidentifikasi faktor yang dapat dijadikan pertimbangan dalam pengembangan layanan mobile payment di masa mendatang.
\end{abstract}

Kata Kunci: Mobile Payment, Continuance Intention, Gender, Structural Equation Modeling

\section{Pendahuluan}

Seiring dengan maraknya layanan seluler dan sistem elektronik, mobile payment (m-payment) semakin berkembang di Indonesia. Berdasarkan survei yang dilakukan oleh World Bank Global Financial Inclusion Data, jumlah pengguna mobile payment di Indonesia mencapai 106 juta pengguna. Kehadiran mobile payment dapat membantu pelanggan menggunakan perangkat seluler tanpa adanya batasan waktu dan tempat (Venkatesh, et al., 2012). 
Berdasarkan survei yang dilakukan oleh Jajak Pendapat, Go-Pay dan OVO menduduki peringkat teratas dalam penggunaan mobile payment di Indonesia (Jajak Pendapat, 2018). Untuk menganalisis preferensi produk, diambil 1.303 responden menggunakan Go-pay dan 438 responden menggunakan OVO. Dari survei yang dilakukan, pengguna laki-laki dan pengguna perempuan memiliki preferensi yang berbeda. Hasil survei ditunjukkan pada Gambar 1.

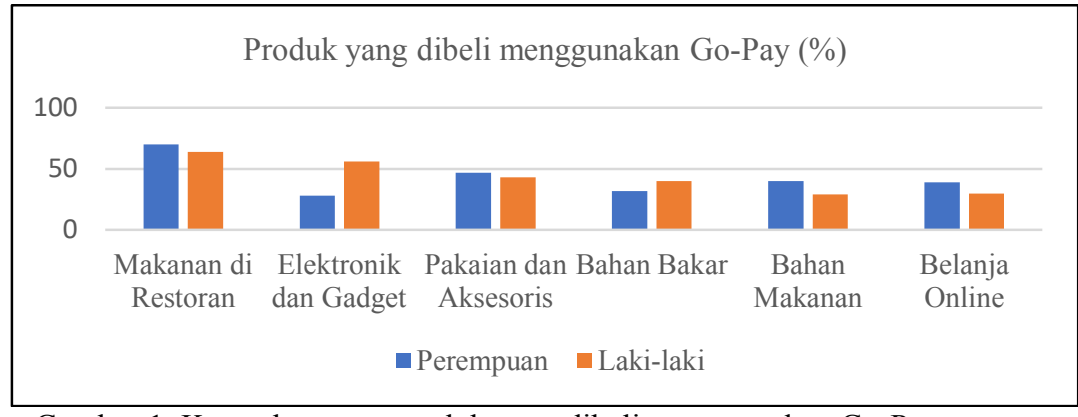

Gambar 1. Kecenderungan produk yang dibeli menggunakan Go-Pay

Pada Gambar 1, pengguna laki-laki lebih memilih menggunakan Go-Pay untuk barang-barang seperti bahan bakar, elektronik dan gadget, serta membayar transaksi belanja online. Sedangkan, pengguna perempuan lebih memilih untuk menggunakannya pada bahan makanan dan belanja online. Hasil yang didapat pun tidak jauh berbeda dengan pengguna OVO. Dari 438 responden, pengguna laki-laki lebih cenderung menggunakan OVO untuk membeli bahan bakar dan penarikan uang. Sedangkan perempuan cenderung menggunakannya untuk bahan makanan dan membayar parkir (Jajak Pendapat, 2018).

Namun, permasalahan yang ditemukan adalah masih banyak responden yang keberatan untuk menggunakan Go-Pay sebagai alat dalam bertransaksi, yakni sebanyak $42 \%$ dari responden dan lebih memilih untuk membayar secara tunai. Hanya $29 \%$ dari keseluruhan pengguna yang memiliki saldo di Go-Pay. Salah satu alasan pengguna tidak tertarik menggunakan Go-Pay dan OVO adalah masalah kepercayaan akan keamanan menggunakan mobile payment. Responden merasa kurang yakin akan keamanan bertransaksi menggunakan Go-Pay dan OVO. Dapat disimpulkan bahwa kepercayaan merupakan hal yang penting dalam menyediakan layanan mobile payment, dan bagaimana membangun kepercayaan dalam layanan mobile payment menjadi pokok bahasan yang penting.

Beberapa penelitian sebelumnya berfokus pada reputasi untuk membangun kepercayaan komersil (Oliveira, et al., 2014), dan lebih berfokus pada satu perspektif teoritis. Lebih spesifiknya, laki-laki lebih berorientasi terhadap hasil yang didapat dan lebih fokus terhadap kinerja aktual, sedangkan perempuan cenderung berorientasi terhadap proses dan lebih memikirkan masalah keamanan dan privasi dalam suatu aktivitas. Dalam konteks IT, laki-laki dan perempuan bersikap berbeda terkait bagaimana mereka menyikapi dan menggunakan IT itu sendiri (Venkatesh, et al., 2012; Zhou, et al., 2014; Lin, et al., 2016). Beberapa studi telah mengidentifikasi permasalahan jenis kelamin yang berbeda terhadap proses bisnis terkait Internet atau teknologi bergerak. (Venkatesh, et al., 2012; Zhou, et al., 2014; Lin, et al., 2016).

\section{Tinjauan Pustaka}

(1) Mobile Payment Tujuan jangka panjang Mobile Payment adalah untuk mengintegrasi semua pembayaran (menggunakan uang, transfer bank, kartu kredit dan lain sebagainya) dan menyediakan sebuah alternatif yang menggunakan berbagai saluran dengan cara yang homogen. (2) Structural Equation Modeling terdiri dari dua model yang saling terkait yaitu structured model dan measurement model. Merupakan salah satu analisis multivariat yang dapat menganalisis hubungan antar variabel secara lebih kompleks. Metode ini dapat menganalisis hubungan antara observed variable dan latent variable, serta hubungan antara latent variable dengan latent variable yang lain. (3) Go-Pay adalah uang elektronik atau dompet digital atau dompet virtual berupa saldo Go-Jek dan dapat digunakan untuk membayar berbagai layanan Go-Jek. Tidak hanya layanan Go-Jek, saat ini Go-Pay juga dapat digunakan untuk berbagai merchant mulai dari restoran, toko buku, toko baju, dan sebagainya. (4) OVO merupakan dompet digital untuk bertransaksi dan mengumpulkan poin di banyak tempat. OVO dapat 
digunakan di semua merchant bertanda OVO, baik restoran, toko baju, dan lainnya. OVO yang kini sudah memiliki lebih dari 500.000 rekan usaha pada gerai offline. (5) Model yang diimplementasikan menggunakan penelitian dari paper acuan. Model penelitian dapat dilihat pada Gambar 2.

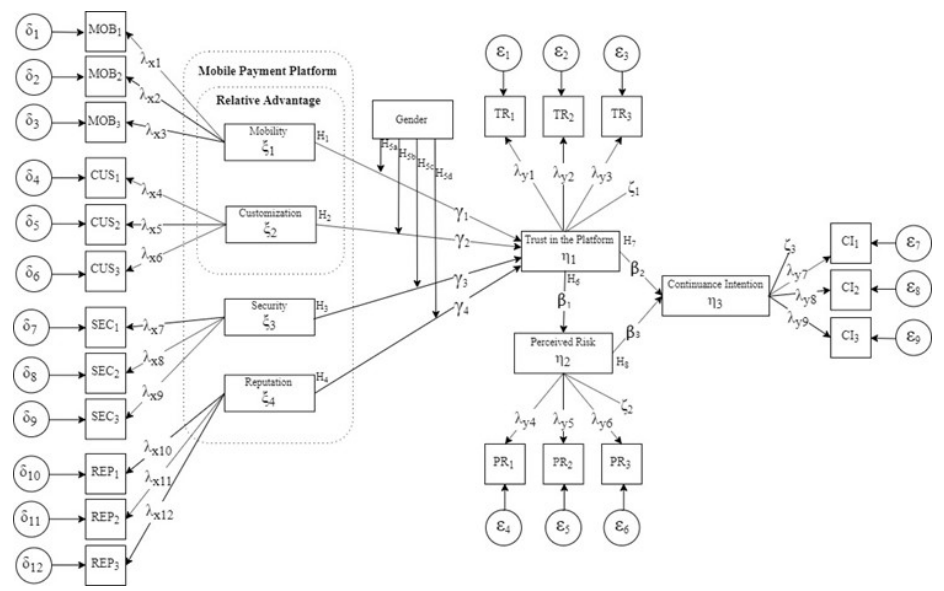

Gambar 2. Model Penelitian

(6) Innovation Diffusion Theory (IDT) menjadi salah satu teori yang berpengaruh dan digunakan secara luas untuk menginvestigasi faktor apa saja yang membuat seorang individu memutuskan untuk mengadopsi sebuah inovasi atau teknologi baru (Yang, et al., 2015). (7) Mobility adalah faktor yang paling berpengaruh dalam mobile commerce, termasuk layanan mobile payment yang terintegrasi menjadi mobile terminal yang bisa dibawa ke mana saja (Mallat, 2007), (Au \& Kauffman, 2008). (8) Customization didefinisikan sebagai kemampuan pengguna untuk mengatur fungsi informasi, metode pembayaran dan pengaturan keamanan sesuai dengan keinginan dan kebiasaan mereka (Huang, et al., 2014). (9) Dalam konteks mobile payment, security merepresentasikan persepsi pengguna dalam safety dan reliability dari struktur organisasi seperti garansi, regulasi dan penawaran dalam transaksi di konteks mobile payment (Zhou, 2011). (10) Reputasi diartikan sebagai keyakinan dari pengguna yang merasa bahwa suatu perusahaan memiliki kesan yang baik tentang ability, benevolence dan integrity (Kim, et al., 2009). (11) Literatur psikologi sosial mengimplikasikan adanya perbedaan kebiasaan yang signifikan antara laki-laki dan perempuan dalam pengambilan keputusan karena orientasi sikap dan kebiasaan yang berbeda (Kim, et al., 2010). Contohnya, dari segi logika kognitif, laki-laki dan perempuan berbeda dalam mencari atau memproses informasi dan mengevaluasi produk (Venkatesh, et al., 2000). (12) Perceived risk dan trust diidentifikasikan sebagai dua pengaruh intensi pengguna dalam literature electronic commerce (McKnight, et al., 2002; Pavlou \& Gefen, 2004; Teo \& Liu, 2007) dan penelitian mobile commerce (Mallat, 2007; Lu, et al., 2011; Lin, et al., 2014). Sehingga, dapat dibentuk hipotesis berikut:

Tabel 1. Hipotesis Penelitian

\begin{tabular}{l|l}
\hline \multicolumn{1}{c|}{ Kode } & \multicolumn{1}{c}{ Hipotesis } \\
\hline$H_{1}$ & Mobility berpengaruh positif terhadap trust dalam layanan mobile payment. \\
$H_{2}$ & Customization berpengaruh positif terhadap trust dalam layanan mobile payment. \\
$H_{3}$ & Security berpengaruh positif terhadap trust dalam layanan mobile payment. \\
$H_{4}$ & Reputation berpengaruh positif terhadap trust dalam layanan mobile payment. \\
$H_{5 a}$ & Dampak mobility pada trust lebih tinggi untuk pengguna laki-laki daripada pengguna perempuan. \\
$H_{5 b}$ & Dampak customization pada trust lebih tinggi untuk pengguna perempuan daripada pengguna laki-laki. \\
$H_{5 c}$ & Dampak security pada trust lebih tinggi untuk pengguna perempuan daripada pengguna laki-laki. \\
$H_{5 d}$ & Dampak reputation terhadap trust lebih tinggi untuk pengguna laki-laki daripada pengguna perempuan. \\
$H_{6}$ & Trust berpengaruh negatif terhadap perceived risk dalam layanan mobile payment. \\
$H_{7}$ & Trust berpengaruh positif terhadap continuance intention dalam menggunakan layanan mobile payment. \\
$H_{8}$ & Perceived Risk berpengaruh negatif terhadap continuance intention dalam menggunakan layanan mobile \\
\hline \hline
\end{tabular}




\section{Metode Penelitian}

Bagian ini menjelaskan metodologi yang digunakan dalam pengerjaan penelitian ini.
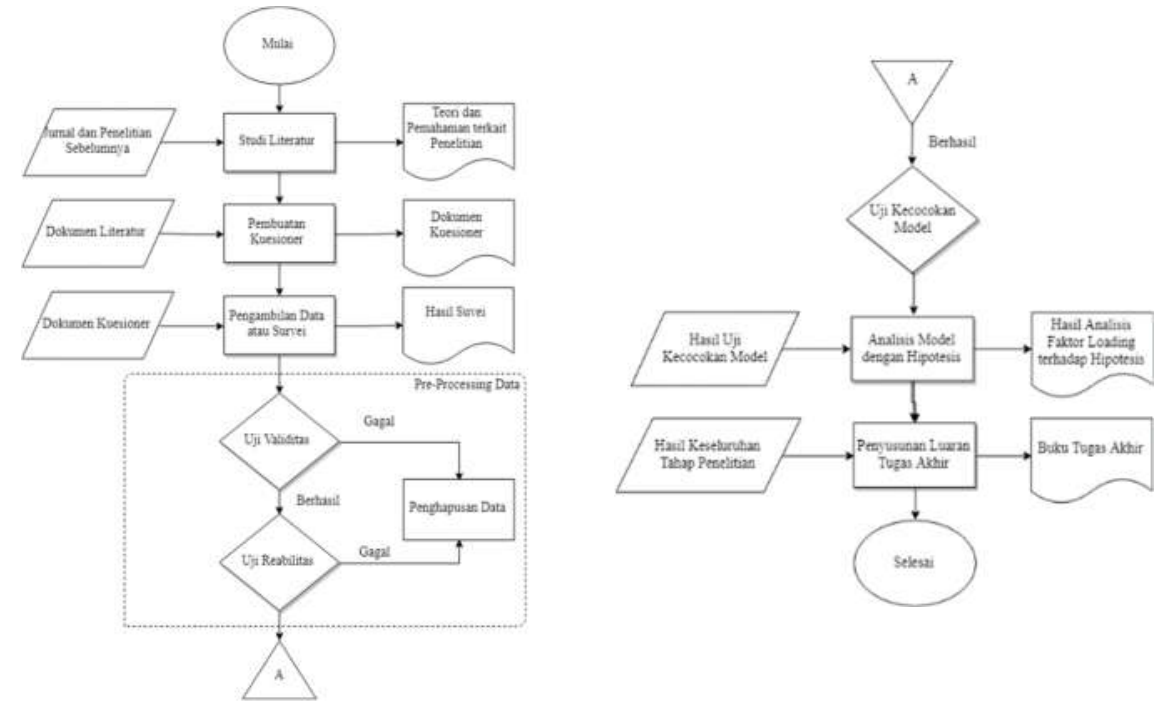

(a) Studi literatur merupakan tahap pencarian dan pemahaman referensi yang berhubungan dengan permasalahan yang ada dalam topik tugas akhir ini. Studi literatur yang akan dibahas antara lain Mobile Payment, Structural Equation Modeling (SEM) dan lain sebagainya. (b) Pembuatan kuesioner merupakan tahap pembuatan kerangka kuesioner sebagai langkah awal pembuatan kuesioner. Kerangka kuesioner akan mengacu pada paper referensi sehingga indikator dan pertanyaan akan dibuat berdasarkan variabel-variabel yang tertera pada paper referensi. (c) Teknis estimasi yang digunakan yaitu maximum likelihood dengan 200 jumlah responden sebagai obyek penelitian. Jumlah tersebut berdasarkan ukuran sampel minimum yang diperlukan untuk mengurangi bias pada semua jenis estimasi SEM (Loehlin, 2004). (d) Pada tahap prepocessing data terdapat 2 uji yang dilakukan yaitu uji validitas dan uji reliabilitas. Sebuah sampel dapat dikatakan valid ketika memiliki validitas yang tinggi atau memberikan hasil ukur yang akurat sesuai dengan tujuan dari uji tersebut (Ghozali, 2006). Uji reliabilitas merupakan pengujian untuk memastikan data tersebut reliabel atau tidak. Kuesioner dinyatakan reliabel jika data yang ada konsisten (Ghozali, 2006). (e) Pada tahap uji kecocokan model yang menggunakan SEM akan mengacu pada indikator yang ada. Indikator yang akan diukur meliputi CMIN/DF, Goodness of Fit Index (GFI), Adjusted Goodness of Fit Index (AGFI), Normal Fit Index (NFI), Comparative Fit Index (CFI), dan Root Mean Square Error of Approximation (RMSEA). (d) Pada tahap analisis model menggunakan hipotesis dilakukan analisis hipotesis dimana model yang telah memenuhi uji kecocokan akan dibandingkan nilai antar variabel yang kemudian dianalisis dengan hipotesis. (f) Pada tahap pembuatan luaran tugas akhir dilakukan penulisan atau dokumentasi penelitian dari tahap pertama hingga tahap terakhir.

\section{Impelementasi}

Dari keseluruhan data, didapatkan 1000 data yang dapat diolah untuk menyelesaikan penelitian ini. Demografi responden yang diperoleh adalah sebagai berikut: (a) Jenis Kelamin: Dari 1000 responden, dapat diketahui bahwa jumlah responden perempuan sebanyak 634 responden (63\%), sedangkan jumlah responden laki-laki sebanyak 366 responden (37\%). (b) Domisili Responden: Dari 1000 responden, domisili terbanyak terdapat pada Provinsi Jawa Timur, DKI Jakarta, dan Daerah Istimewa Yogyakarta. (c) Usia Responden: Pada responden perempuan, terdapat 593 responden (94\%) berusia 17-22 tahun, 26 responden (4\%) berusia 23-28 tahun dan 15 responden (2\%) berusia 29-38 tahun. Pada responden laki-laki, terdapat 333 responden (91\%) berusia 17-22 tahun, 28 responden (8\%) berusia 23-28 tahun dan 5 responden (1\%) berusia 29-38 tahun. (d) Profesi Responden: Berdasarkan hasil kuesioner 
penelitian, pada responden perempuan terdapat 574 responden $(90,5 \%)$ berprofesi sebagi Pelajar/Mahasiswa, 4 responden $(0,6 \%)$ berprofesi sebagai PNS, 6 responden $(0,9 \%)$ berprofesi sebagai Karyawan BUMN, 31 responden (4,9\%) berprofesi sebagai Karyawan Swasta, 1 responden $(0,2 \%)$ berprofesi sebagai Wiraswasta, 9 responden $(1,4 \%)$ berprofesi sebagai Ibu Rumah Tangga dan 9 responden $(1,4 \%)$ berprofesi lain yang tidak tercantum dalam daftar. Berdasarkan hasil penelitian dengan responden laki-laki, sebanyak 318 responden (86,9\%) berprofesi sebagai Pelajar/Mahasiswa, 4 responden $(1,1 \%)$ berprofesi sebagai PNS, 8 responden $(2,2 \%)$ berprofesi sebagai Karyawan BUMN, 24 responden $(6,6 \%)$ berprofesi sebagai Karyawan Swasta, 5 responden $(1,4 \%)$ berprofesi sebagai Wiraswasta, dan 7 responden $(1,9 \%)$ berprofesi lain yang tidak tercantum dalam daftar. (e) Aplikasi Mobile Payment yang Digunakan: Berdasarkan hasil kuesioner penelitian pada responden perempuan, terdapat 110 responden $(30,1 \%)$ yang menggunakan Go-Pay, 192 responden $(52,5 \%)$ yang menggunakan OVO dan 332 responden $(90,7 \%)$ menggunakan Go-Pay dan OVO sebagai aplikasi Mobile Payment. Berdasarkan hasil kuesioner penelitian pada responden laki-laki, terdapat 66 responden $(18,0 \%)$ yang menggunakan Go-Pay, 102 responden $(27,9 \%)$ yang menggunakan OVO dan 198 responden $(54,1 \%)$ yang menggunakan Go-Pay dan OVO sebagai aplikasi Mobile Payment. (f) Berapa kali responden menggunakan Mobile Payment: Berdasarkan hasil kuesioner penelitian, pada responden perempuan terdapat 579 responden (91,3\%) menggunakan Mobile Payment sebanyak lebih dari 5 kali, 48 responden (7,6\%) menggunakan Mobile Payment sebanyak 2-5 kali dan 7 responden $(1,1 \%)$ hanya 1 kali menggunakan Mobile Payment dalam bertransaksi. Pada hasil kuesioner penelitian dengan responden laki-laki, terdapat 311 responden (85,0\%) menggunakan Mobile Payment sebanyak lebih dari 5 kali, 51 responden (13,9\%) menggunakan Mobile Payment sebanyak 2-5 kali dan 4 responden $(1,1 \%)$ hanya 1 kali menggunakan Mobile Payment dalam bertransaksi. (g) Kapan terakhir kali responden menggunakan Mobile Payment: Pada hasil kuesioner penelitian dengan responden perempuan, sebanyak 431 responden $(68,0 \%)$ bertransaksi menggunakan Mobile Payment dalam 3 hari kemarin, 119 responden (18,8\%) bertransaksi menggunakan Mobile Payment dalam 1 minggu yang lalu, 60 responden (9,5\%) bertransaksi menggunakan Mobile Payment dalam 1 bulan yang lalu dan 24 responden (3,8\%) bertransaksi menggunakan Mobile Payment lebih dari 1 bulan yang lalu. Pada hasil kuesioner penelitian pada responden laki-laki, sebanyak 221 responden $(60,4 \%)$ bertransaksi menggunakan Mobile Payment dalam 3 hari kemarin, 85 responden $(23,2 \%)$ bertransaksi menggunakan Mobile Payment dalam 1 minggu yang lalu, 36 responden (9,8\%) menggunakan Mobile Payment dalam 1 bulan yang lalu dan 24 responden (6,6\%) bertransaksi menggunakan Mobile Payment lebih dari 1 bulan yang lalu.

\section{Hasil dan Pembahasan}

Pada pre-processing data ini dilakukan dua jenis pengujian untuk menguji data kuesioner yang telah didapatkan, yakni Uji Validitas dan Uji Reliabilitas.

Tabel 2. Hasil Uji Validitas Kuesioner

\begin{tabular}{c|ccc}
\hline \hline Indikator & Nilai $\boldsymbol{r}$ hitung & Nilai $\boldsymbol{r}$ tabel & Keterangan \\
\hline MOB1 & 0,534 & 0,279 & Valid \\
MOB2 & 0,679 & 0,279 & Valid \\
MOB3 & 0,698 & 0,279 & Valid \\
CUS1 & 0,707 & 0,279 & Valid \\
CUS2 & 0,602 & 0,279 & Valid \\
CUS3 & 0,680 & 0,279 & Valid \\
SEC1 & 0,649 & 0,279 & Valid \\
SEC2 & 0,635 & 0,279 & Valid \\
SEC3 & 0,633 & 0,279 & Valid \\
REP1 & 0,569 & 0,279 & Valid \\
REP2 & 0,465 & 0,279 & Valid \\
REP3 & 0,416 & 0,279 & Valid \\
TR1 & 0,629 & 0,279 & Valid \\
TR2 & 0,624 & 0,279 & Valid \\
TR3 & 0,564 & 0,279 & Valid \\
\hline
\end{tabular}




\begin{tabular}{l|lll}
\hline PR1 & 0,411 & 0,279 & Valid \\
PR2 & 0,344 & 0,279 & Valid \\
PR3 & 0,417 & 0,279 & Valid \\
CI1 & 0,713 & 0,279 & Valid \\
CI2 & 0,622 & 0,279 & Valid \\
CI3 & 0,641 & 0,279 & Valid \\
\hline \hline
\end{tabular}

Sehingga, dapat dikatakan bahwa data yang digunakan dalam penelitian ini adalah data yang sebenarnya dan valid. Keterangan: $\mathrm{MOB}=$ Mobility; $\mathrm{CUS}=$ Customization; $\mathrm{SEC}=$ Security; $\mathrm{REP}=$ Reputation; $\mathrm{TR}=$ Trust in the Platform; $\mathrm{PR}=$ Perceived Risk $; \mathrm{CI}=$ Continuance Intention. Dalam Uji Reliabilitas dengan menggunakan data responden yang sama dengan Uji Validitas, didapatkan hasil Cronbach's Alpha 0,893 dimana nilai tersebut telah memenuhi nilai minimum yakni 0,6. Hal ini dapat dikatakan bahwa Uji Reliabilitas pada kuesioner ini adalah reliabel.

Pada Uji Asumsi Klasik, seluruh sample akan dibagi menjadi dua sub-sample, mengacu pada (Keil, 2000). Dilakukan multiple group analysis untuk membandingkan perbedaan kedua sub-sample (perempuan dan laki-laki) dalam semua hubungan antar variabel. Prosedur ini diadopsi dari literatur (Zhou, et al., 2014; Sia, 2009; Shao, et al., 2019). Uji Normalitas dilakukan untuk mengetahui data yang akan diolah untuk tahapan selanjutnya memiliki distribusi normal. Pengukuran Skewness dan Kurtosis merupakan salah satu cara untuk mengidentifikasi distribusi data secara univariate. Data berdistribusi normal jika memenuhi nilai Zskewness, di mana batas nilai yang digunakan adalah di antara \pm 3 dan nilai Zkurtosis berada di antara \pm 8 (Kwok, 2018).

Tabel 3. Hasil Uji Normalitas

\begin{tabular}{|c|c|c|c|c|}
\hline Gender & Variabel & $\begin{array}{c}\text { Rasio } \\
\text { Skewness }\end{array}$ & $\begin{array}{c}\text { Rasio } \\
\text { Kurtosis }\end{array}$ & Ket. \\
\hline \multirow{5}{*}{ Perempuan } & MOB & $-2,061$ & $-2,195$ & Normal \\
\cline { 2 - 5 } & CUS & $-2,835$ & $-4,706$ & Normal \\
\cline { 2 - 5 } & SEC & $-1,134$ & $-3,242$ & Normal \\
\cline { 2 - 5 } & REP & $-2,701$ & $-2,206$ & Normal \\
\cline { 2 - 5 } & TR & $-2,329$ & $-1,974$ & Normal \\
\cline { 2 - 5 } & PR & $-2,144$ & $-2,793$ & Normal \\
\cline { 2 - 5 } & $\mathrm{CI}$ & $-2,690$ & $-2,402$ & Normal \\
\hline \multirow{5}{*}{ Laki-laki } & MOB & $-1,585$ & $-2,322$ & Normal \\
\cline { 2 - 5 } & CUS & $-2,976$ & $-3,314$ & Normal \\
\cline { 2 - 5 } & SEC & $-1,671$ & $-2,551$ & Normal \\
\cline { 2 - 5 } & REP & $-2,500$ & $-2,055$ & Normal \\
\cline { 2 - 5 } & TR & $-2,132$ & $-1,472$ & Normal \\
\cline { 2 - 5 } & PR & $-2,492$ & $-0,803$ & Normal \\
\cline { 2 - 5 } & $\mathrm{CI}$ & $-1,453$ & $-2,440$ & Normal \\
\hline
\end{tabular}

Tabel 4. Hasil Uji Multikolinearitas

\begin{tabular}{|c|c|c|c|}
\hline \multicolumn{4}{|c|}{ Coefficients $^{a}$} \\
\hline \multirow{2}{*}{ Gender } & \multirow{2}{*}{ Variabel } & \multicolumn{2}{|c|}{ Collinearity Statistic } \\
\hline & & Tolerance & VIF \\
\hline \multirow{6}{*}{ Perempuan } & MOB & 0,755 & 1,325 \\
\hline & CUS & 0,722 & 1,384 \\
\hline & SEC & 0,701 & 1,427 \\
\hline & REP & 0,725 & 1,380 \\
\hline & TR & 0,530 & 1,887 \\
\hline & $\mathrm{PR}$ & 0,903 & 1,107 \\
\hline \multirow{6}{*}{ Laki-laki } & MOB & 0,761 & 1,315 \\
\hline & CUS & 0,617 & 1,620 \\
\hline & SEC & 0,662 & 1,511 \\
\hline & REP & 0,667 & 1,500 \\
\hline & TR & 0,506 & 1,977 \\
\hline & PR & 0,865 & 1,156 \\
\hline
\end{tabular}

a. Dependent Variable: CI

Berdasarkan Tabel 6, pada perempuan dan laki-laki memiliki nilai tolerance $>0,10$ dan nilai VIF $<$ 10,00. Sehingga dapat disimpulkan bahwa data penelitian tugas akhir ini tidak terjadi multikolinearitas dalam model regresi.

Tabel 5. Hasil Uji Validitas Instrumen

\begin{tabular}{|c|c|c|c|c|}
\hline \multirow{2}{*}{$\begin{array}{l}\text { Indi- } \\
\text { kator }\end{array}$} & Perempuan & $\begin{array}{l}\text { Laki- } \\
\text { laki }\end{array}$ & \multirow{2}{*}{$\begin{array}{l}\text { Nilai } \\
\text { Min. }\end{array}$} & \multirow[t]{2}{*}{ Ket. } \\
\hline & $\begin{array}{l}\text { Loading } \\
\text { Factor }\end{array}$ & $\begin{array}{c}\text { Loading } \\
\text { Factor }\end{array}$ & & \\
\hline MOB1 & 0,62 & 0,53 & 0,50 & Valid \\
\hline MOB2 & 0,72 & 0,71 & 0,50 & Valid \\
\hline MOB3 & 0,71 & 0,66 & 0,50 & Valid \\
\hline CUS1 & 0,67 & 0,75 & 0,50 & Valid \\
\hline CUS2 & 0,75 & 0,66 & 0,50 & Valid \\
\hline CUS3 & 0,81 & 0,72 & 0,50 & Valid \\
\hline SEC1 & 0,83 & 0,80 & 0,50 & Valid \\
\hline SEC2 & 0,84 & 0,88 & 0,50 & Valid \\
\hline
\end{tabular}

\begin{tabular}{|l|l|l|l|l|}
\hline SEC3 & 0,82 & 0,85 & 0,50 & Valid \\
\hline REP1 & 0,74 & 0,74 & 0,50 & Valid \\
\hline REP2 & 0,71 & 0,62 & 0,50 & Valid \\
\hline REP3 & 0,44 & 0,47 & 0,50 & $\begin{array}{c}\text { Tidak } \\
\text { Valid }\end{array}$ \\
\hline TR1 & 0,77 & 0,74 & 0,50 & Valid \\
\hline TR2 & 0,77 & 0,70 & 0,50 & Valid \\
\hline TR3 & 0,79 & 0,80 & 0,50 & Valid \\
\hline PR1 & 0,65 & 0,58 & 0,50 & Valid \\
\hline PR2 & 0,87 & 0,87 & 0,50 & Valid \\
\hline PR3 & 0,66 & 0,75 & 0,50 & Valid \\
\hline CI1 & 0,87 & 0,87 & 0,50 & Valid \\
\hline CI2 & 0,74 & 0,69 & 0,50 & Valid \\
\hline CI3 & 0,90 & 0,86 & 0,50 & Valid \\
\hline
\end{tabular}


Tabel 6. Hasil Uji Reliabilitas Instrumen

\begin{tabular}{|c|c|c|c|c|c|}
\hline \multirow[b]{2}{*}{$\begin{array}{c}\text { Indikato } \\
\mathbf{r}\end{array}$} & \multicolumn{2}{|c|}{ Perempuan } & \multicolumn{2}{|c|}{ Laki-laki } & \multirow[b]{2}{*}{ Ket. } \\
\hline & $\begin{array}{c}\text { CR } \\
\geq 0,6\end{array}$ & $\begin{array}{c}V E \geq 0, \\
4\end{array}$ & $\begin{array}{c}\text { CR } \\
\geq 0,6\end{array}$ & $\begin{array}{c}\mathrm{VE} \geq 0, \\
4\end{array}$ & \\
\hline MOB1 & \multirow{3}{*}{$\begin{array}{c}0,72 \\
4\end{array}$} & \multirow{3}{*}{0,468} & \multirow{3}{*}{$\begin{array}{c}0,67 \\
0\end{array}$} & \multirow{3}{*}{0,407} & \multirow{3}{*}{$\underset{t}{\text { Akura }}$} \\
\hline MOB2 & & & & & \\
\hline MOB3 & & & & & \\
\hline CUS1 & \multirow{3}{*}{$\begin{array}{c}0,78 \\
8\end{array}$} & \multirow{3}{*}{0,554} & \multirow{3}{*}{$\begin{array}{c}0,75 \\
1\end{array}$} & \multirow{3}{*}{0,502} & \multirow{3}{*}{$\underset{t}{\text { Akura }}$} \\
\hline CUS2 & & & & & \\
\hline CUS3 & & & & & \\
\hline SEC1 & 0,87 & 0600 & 0,88 & 0712 & Akura \\
\hline SEC2 & 0 & 0,090 & 2 & 0,113 & $\mathrm{t}$ \\
\hline
\end{tabular}

\begin{tabular}{|c|c|c|c|c|c|}
\hline SEC3 & & & & & \\
\hline REP1 & \multirow{2}{*}{$\begin{array}{c}0,68 \\
1\end{array}$} & \multirow{2}{*}{0,518} & 0,63 & \multirow{2}{*}{0,465} & \multirow{2}{*}{$\underset{t}{\text { Akura }}$} \\
\hline REP2 & & & 0 & & \\
\hline TR1 & \multirow{3}{*}{$\begin{array}{c}0,82 \\
4\end{array}$} & \multirow{3}{*}{0,610} & & \multirow{3}{*}{0,560} & \multirow{3}{*}{$\begin{array}{c}\text { Akura } \\
\mathrm{t}\end{array}$} \\
\hline TR2 & & & $0, / 9$ & & \\
\hline TR3 & & & & & \\
\hline PR1 & \multirow{3}{*}{$\begin{array}{c}0,77 \\
4\end{array}$} & \multirow{3}{*}{0,540} & & \multirow{3}{*}{0,553} & \multirow{3}{*}{$\begin{array}{c}\text { Akura } \\
\mathrm{t}\end{array}$} \\
\hline PR2 & & & $0, / 8$ & & \\
\hline PR3 & & & & & \\
\hline CI1 & \multirow{3}{*}{$\begin{array}{c}0,87 \\
3\end{array}$} & \multirow{3}{*}{0,697} & & \multirow{3}{*}{0,661} & \multirow{3}{*}{$\begin{array}{c}\text { Akura } \\
\mathrm{t}\end{array}$} \\
\hline CI2 & & & 0,85 & & \\
\hline CI3 & & & & & \\
\hline
\end{tabular}

Berdasarkan perhitungan $\mathrm{CR}$ dan VE pada Tabel 8, semua indikator pada perempuan telah reliabel atau konsisten karena telah memenuhi nilai minimum $C R \geq 0,60$ dan $\mathrm{VE} \geq 0,40$. Sehingga seluruh variabel telah valid dan akurat, maka dapat diikutsertakan dalam pengujian selanjutnya. Setelah data dinyatakan valid dan reliabel atau akurat pada Uji CFA, model akan diuji kesesuaiannya dengan Goodness of Fit dengan melihat nilai CMIN/df, Goodness of Fit Index (GFI), Adjusted Goodness of Fit Index (AGFI), Normal Fit Index (NFI), Comparative Fit Index (CFI) dan Root Mean Square Error of Approximation (RMSEA).

Tabel 7. Hasil Uji Kecocokan Model

\begin{tabular}{|c|c|c|c|c|c|}
\hline $\begin{array}{l}\text { Indeks Uji } \\
\text { Kecocokan }\end{array}$ & $\begin{array}{l}\text { Hasil pada } \\
\text { Perempuan }\end{array}$ & $\begin{array}{c}\text { Hasil pada } \\
\text { Laki-laki }\end{array}$ & Cut Off Value & Ket. Perempuan & Ket. Laki-laki \\
\hline $\mathrm{CMIN} / \mathrm{df}$ & $\begin{array}{c}3,86 \\
(\mathrm{CMIN}=606,66 \\
\text { dan } \mathrm{df}=157)\end{array}$ & $\begin{array}{c}2,36 \\
(\mathrm{CMIN}=370.70 \\
\text { dan } \mathrm{DF}=157)\end{array}$ & $\begin{array}{c}\text { Terrible } \\
(\geq 5) \\
\text { Acceptable } \\
(\geq 3) \\
\text { Excellent } \\
(\geq 1)\end{array}$ & Acceptable & Excellent \\
\hline GFI & 0,91 & 0,90 & $\begin{array}{l}\text { Good fit } \\
(\geq 0,9)\end{array}$ & Good fit & Good fit \\
\hline AGFI & 0,88 & 0,87 & $\begin{array}{c}\text { Good fit } \\
(\geq 0,9) \text { Marginal } \\
\text { fit }(0,8 \leq \text { AGFI } \geq \\
0,9)\end{array}$ & Marginal fit & Marginal fit \\
\hline NFI & 0,96 & 0,94 & $\begin{array}{l}\text { Good fit } \\
(\geq 0,9)\end{array}$ & Good fit & Good fit \\
\hline TLI & 0,96 & 0,96 & $\begin{array}{c}\text { Good fit } \\
(\geq 0,9)\end{array}$ & Good fit & Good fit \\
\hline CFI & 0,97 & 0,96 & $\begin{array}{c}\text { Good fit } \\
(\geq 0,9)\end{array}$ & Good fit & Good fit \\
\hline RSMEA & 0,067 & 0,061 & Good fit $(<0,08)$ & Good fit & Good fit \\
\hline
\end{tabular}

Berdasarkan hasil Uji Kecocokan Model pada Tabel 10, diketahui bahwa semua nilai uji kecocokan model pada perempuan dan laki-laki telah memenuhi cut off value dari SEM. Dimana, nilai ini mengacu pada penelitian (Hu \& B.P.M., 1999) dan penelitian (Wijanto, 2008) dan (California, 2009). Sehingga pada tahapan selanjutnya, model ini dapat langsung masuk ke tahapan analisis dan tidak perlu masuk ke tahapan respesifikasi model, karena tahapan tersebut hanya dilakukan jika cut off value belum terpenuhi. Hasil akhir model penelitian merupakan model yang didapatkan setelah semua indeks uji kecocokan model dalam kondisi fit.

Untuk memperjelas pemahaman terkait analisis hipotesis, akan dijabarkan melalui analisis masingmasing poin hipotesis pada berikut ini. (a) H1: Mobility berpengaruh positif terhadap trust dalam layanan Mobile Payment. Berdasarkan nilai hubungan antar variabel menunjukkan bahwa pada perempuan, estimates value yang didapatkan adalah 0,20 dengan t-value 3,81 dan pada laki-laki estimates value yang didapatkan adalah $-0,03$ dengan t-value $-0,29$. Dimana, $\neg$ t-value $\mathrm{MOB} \rightarrow \mathrm{TR}<$ 1,96. Sehingga, dapat disimpulkan bahwa Mobility tidak berpengaruh positif terhadap Trust in the platform. Maka, H1 tidak terpenuhi. (b) H2: Customization berpengaruh positif terhadap trust dalam 
layanan Mobile Payment. Berdasarkan nilai hubungan antar variabel menunjukkan bahwa pada perempuan, estimates value yang didapatkan adalah 0,15 dengan t-value 2,86 dan pada laki-laki estimates value yang didapatkan adalah 0,34 dengan t-value 2,95. Dimana, t-value CUS $\rightarrow$ TR $>1,96$. Sehingga, dapat disimpulkan bahwa Customization berpengaruh positif terhadap Trust in the platform. Maka, H2 terpenuhi. (c) H3: Security berpengaruh positif terhadap trust dalam layanan Mobile Payment. Berdasarkan nilai hubungan antar variabel menunjukkan bahwa pada perempuan, estimates value yang didapatkan adalah 0,21 dengan t-value 4,35 dan pada laki-laki estimates value yang didapatkan adalah 0,19 dengan t-value 2,82. Dimana, $\neg \mathrm{t}$-value SEC $\rightarrow \mathrm{TR}>1$,96. Sehingga, dapat disimpulkan bahwa Security berpengaruh positif terhadap Trust in the platform. Maka, H3 terpenuhi. (d) H4: Reputation berpengaruh positif terhadap trust dalam layanan Mobile Payment. Berdasarkan nilai hubungan antar variabel menunjukkan bahwa pada perempuan, estimates value yang didapatkan adalah 0,52 dengan tvalue 8,72 dan pada laki-laki estimates value yang didapatkan adalah 0,52 dengan t-value 4,32. Dimana, $\neg t$-value REP $\rightarrow$ TR $>1$,96. Sehingga, dapat disimpulkan bahwa Reputation berpengaruh positif terhadap Trust in the platform. Maka, dapat disimpulkan bahwa H4 terpenuhi. (e) H5a: Dampak mobility pada trust lebih tinggi untuk pengguna laki-laki daripada pengguna perempuan. Berdasarkan nilai hubungan antar variabel menunjukkan bahwa pada perempuan, estimates value yang didapatkan adalah 0,20 dengan t-value 3,81 dan pada laki-laki estimates value yang didapatkan adalah - 0,03 dengan t-value $-0,29$. Dimana, $\neg$ t-value MOB pada laki-laki kurang dari t-value MOB pada perempuan. Sehingga, dapat disimpulkan bahwa H5a tidak terpenuhi. (f) H5b: Dampak customization pada trust lebih tinggi untuk pengguna perempuan daripada pengguna laki-laki. Berdasarkan nilai hubungan antar variabel menunjukkan bahwa pada perempuan, estimates value yang didapatkan adalah 0,15 dengan t-value 2,86 dan pada laki-laki estimates value yang didapatkan adalah 0,34 dengan t-value 2,95. Dimana, $\neg$ t-value CUS pada perempuan kurang dari t-value CUS pada laki-laki. Sehingga, dapat disimpulkan bahwa H5b tidak terpenuhi. (g) H5c: Dampak security pada trust lebih tinggi untuk pengguna perempuan daripada pengguna laki-laki. Berdasarkan nilai hubungan antar variabel menunjukkan bahwa pada perempuan, estimates value yang didapatkan adalah 0,21 dengan t-value 4,35 dan pada laki-laki estimates value yang didapatkan adalah 0,19 dengan t-value 2,82. Dimana, $\neg \mathrm{t}$-value SEC pada perempuan lebih tinggi daripada laki-laki. Maka, dapat disimpulkan bahwa H5c terpenuhi. (h) H5d: Dampak reputation terhadap trust lebih tinggi untuk pengguna laki-laki daripada pengguna perempuan. Berdasarkan nilai hubungan antar variabel menunjukkan bahwa pada perempuan, estimates value yang didapatkan adalah 0,52 dengan t-value 8,72 dan pada laki-laki estimates value yang didapatkan adalah 0,52 dengan t-value 4,32. Dimana, t-value REP pada perempuan lebih tinggi daripada laki-laki. Maka, dapat disimpulkan bahwa H5d tidak terpenuhi. (i) H6: Trust berpengaruh negatif terhadap perceived risk dalam layanan Mobile Payment. Berdasarkan nilai hubungan antar variabel menunjukkan bahwa pada perempuan, estimates value yang didapatkan adalah $-0,37$ dengan t-value $-7,19$ dan pada laki-laki estimates value yang didapatkan adalah $-0,46$ dengan t-value $-6,43$. Dimana, $\neg$ t-value TR $\rightarrow$ PR $<0$. Sehingga, dapat disimpulkan bahwa Trust berpengaruh negatif terhadap perceived risk. Maka, dapat disimpulkan bahwa H6 terpenuhi. (j) H7: Trust berpengaruh positif terhadap continuance intention dalam menggunakan layanan Mobile Payment. Berdasarkan nilai hubungan antar variabel menunjukkan bahwa pada perempuan, estimates value yang didapatkan adalah 0,58 dengan t-value 12,29 dan pada laki-laki estimates value yang didapatkan adalah 0,59 dengan t-value 8,92. Dimana, $\neg$ t-value $\mathrm{TR} \rightarrow \mathrm{CI}>0$. Sehingga, dapat disimpulkan bahwa Trust berpengaruh positif terhadap continuance intention. Maka, dapat disimpulkan bahwa H7 terpenuhi. (k) H8: Perceived Risk berpengaruh negatif terhadap continuance intention dalam menggunakan layanan Mobile Payment. Berdasarkan nilai hubungan antar variabel menunjukkan bahwa pada perempuan, estimates value yang didapatkan adalah $-0,10$ dengan tvalue $-2,41$ dan pada laki-laki estimates value yang didapatkan adalah $-0,10$ dengan $t$-value $-2,41$. Dimana, $t$-value $\mathrm{PR} \rightarrow \mathrm{CI}<0$. Sehingga, dapat disimpulkan bahwa Perceived risk berpengaruh negatif terhadap continuance intention. Maka, dapat disimpulkan bahwa $\mathrm{H} 8$ terpenuhi.

Dari beberapa penelitian terkait, berikut adalah rekomendasi variabel yang dapat digunakan untuk penelitian selanjutnya. (a) Perceived Ease of Use: Adanya beberapa keterbatasan pada telepon seluler 
menjadikan ease of use salah satu faktor pendukung penggunaan mobile application. Hal ini didukung karena pada layanan mobile payment memerlukan solusi pembayaran yang sudah mapan sehingga dibutuhkan adanya kemudahan dalam penggunaan. Beberapa contoh penggunaan yang mudah (ease of use) meliputi beberapa aspek, seperti simbol dan tombol fungsi yang jelas, beberapa langkah sederhana, tampilan grafis dan fungsi bantuan (Pagani \& Schipani, 2005). Oleh karena itu, perceived ease of use dapat ditambahkan ke dalam model untuk penelitian yang selanjutnya. (b) Monetary Rewards: Adanya manfaat nyata yang dirasakan oleh pengguna seperti cashback, kupon, diskon dan penawaran promosi (Wang, et al., 2019). Variabel ini diusulkan karena dapat mengetahui apakah dengan adanya monetary rewards dapat membuat pengguna terus menggunakan layanan mobile payment. Terbukti dengan adanya monetary rewards, dapat meningkatkan respon yang baik (Goritz, 2006). Selain itu, penelitian terkait keamanan informasi dan privasi menyarankan bahwa dengan adanya reward ini dapat mendorong pengguna untuk memberikan informasi pribadinya (Hann, et al., 2007; Hui, et al., 2007).

\section{Referensi}

Au, Y. A. \& Kauffman, R. J., 2008. The economics of mobile payments: Understanding stakeholder issues for an emerging financial technology application. Electronic Commerce Research and Application, 7(2), pp. 141-164.

Awad, N. F. \& Ragowsky, A., 2008. Establishing trust in electronic commerce through online word of mouth: an examination across genders. Journal of Management Information Systems, Volume 24, pp. 101-121.

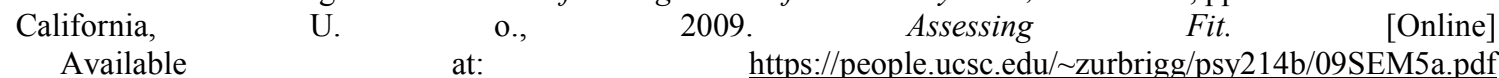
[Diakses 0611 2019].

Cho, D.-Y., Kwon, H. J. \& Lee, N. H.-Y., 2007. Analysis of trust in internet and mobile commerce adoption. Hawaii, IEEE Proceedings of the 40th Hawaii International Conference on System Science.

Fornell, D., 1981. Evaluating structural equation models with unobserveable variables and measurement error. Journal of Marketing Research, pp. 39-50.

Ghozali, I., 2006. Aplikasi analisis multivariate dengan program SPSS. Semarang: Badan Penerbit Universitas Diponegoro.

Goritz, A. S., 2006. Incentives in web studies: methodological issues and a review. International Journal of Internet Science, 1(1), pp. 58-70.

Hann, I. H., Hui, K.-L., Lee, S.-Y. \& L., I., 2007. Overcoming online information privacy concerns: an information-processing theory approach. Journal of Management Information Systems, 24(2), pp. 13-42.

Huang, L., Ba, S. \& Lu, X., 2014. Building online trust in a culture of confucianism: The impact of process flexilbility and perceived control. ACM Transactions on Management Information Systems, Volume 25.

Hui, K., Teo, H. H. \& Lee, S. Y. T., 2007. The value of privacy assurance: an exploratory field experiment. MIS Quarterly, 31(1), pp. 19-33.

Hu, L. \& B.P.M., 1999. Cutoff criteria for fit indexes in covariance structure analysis: Conventional criteria versus new alternatives. Structural Equation Modeling: A Multidisciplinary Journal, 6(1), pp. 1-55.

Jajak Pendapat, 2018. Cashless payment: Extended usage of Go-Pay and OVO. [Online] Available at: https://jajakpendapat.net/pdf/12887/cashless-payment:-extended-usage-of-go-pay-and-ovo [Diakses 2004 2019].

Jajak Pendapat, 2018. Mobile payment in Indonesia. [Online] Available at: https://jajakpendapat.net/pdf/16869/indonesia-mobile-payment-trend-2018---jakpat-free-surveyreport

[Diakses 2004 2019].

Keil, M., 2000. A cross-cultural study on escalation of commitment behavior in software projects. MIS Quarterly, 24(2), pp. 299-325.

Kim, C., Mirusmonov, M. \& Lee, I., 2010. An empirical examination of factors influencing the intention to use mobile payment. Computers in Human Behavior, 26(3), pp. 310-322.

Kim, G., Shin, B. \& Lee, H. G., 2009. Understanding dynamics between initial trust and usage intentions of mobile banking. Information Systems Journal, 19(3).

Kim, K. K. \& Prabhakar, B., 2004. Initial trust and the adoption of B2C e-commerce. ACM SIGMIS Database, 35(2), pp. 50-64.

Kwok, O.-M., 2018. Editorial: recent advancements in structural equation modeling (SEM): From both methodological and application perspectives.. Frontiers in Psychology, Volume 9.

Lee, H., 2015. Compensation paradox: the influence of monetary rewards on user behaviour. Behaviour \& Information Technology, 34(1), pp. 45-56. 
Lin, J., Wang, B., Wang, N. \& Lu, Y., 2014. Understanding the evolution of consumer trust in mobile commerce: A longitudinal study. Information Technology and Management, Volume 15, pp. 37-49.

Lin, X., Featherman, M. \& Sarker, S., 2016. Understanding factors affecting users' social networking site continuance: A gender difference perspective. Information \& Management, Volume 54

Loehlin, J., 2004. Latent variable models: An introduction to factor, path, and structural equation analysis: Fourth edition. Journal of Educational Statistics, Volume 12.

Lu, Y., Yang, S., Chau, P. Y. \& Cao, Y., 2011. Dynamics between the trust transfer process and intention to use mobile payment services: A cross-environment perspective. Information \& Management, 48(8), pp. 393-403.

Mallat, N., 2007. Exploring consumer adoption of mobile payments - A qualitative study. The Journal of Strategic Information Systems, 16(4), pp. 413-432.

McKnight, D. H., Choudhury, V. \& Kacmar, C., 2002. The impact of initial consumer trust on intentions to transact with a website: A trust building model. The Journal of Strategic Information Systems, 11(3-4), pp. $297-323$.

McKnight, D. H., Cummings, L. L. \& Chervany, N. L., 1998. Initial trust formation in new organizational relationships. Academy of Management Review, 23(3), pp. 473-490.

Oliveira, T., Faria, M., Thomas, M. A. \& Popovic, A., 2014. Extending the understanding of mobile banking adoption: When UTAUT meets TTF and ITM. International Journal of Information Management, 34(5), pp. 689-703.

Pagani, M. \& Schipani, D., 2005. Motivations and barriers to the adoption of $3 \mathrm{G}$ mobile multimedia services. Ecommerce and M-commerce Technologies, pp. 80-95.

Pavlou, P. A. \& Gefen, D., 2004. Building effective online marketplaces with institution-based trust. Information Systems Research, 15(1), pp. 37-59.

Shao, Z., Zhang, L., Li, X. \& Guo, Y., 2019. Antecedents of trust and continuance intention in mobile payment platforms: The moderating effect of gender. Electronic Commerce Research and Applications, Volume 33, p. 100823.

Shopback, 2016. Perilaku konsumen di Indonesia menjelang hari belanja online nasional. [Online] Available at: https://technologue.id/survei-shopback-promo-dan-diskon-harbolnas-2016-tetap-jadi-incarankonsumen/amp/ [Diakses 01112019$].$

Sia, C. L., 2009. Web strategies to promote internet shopping: Is cultural-customization needed?. MIS Quarterly, 33(3), pp. 491-512.

Sugiyono, 2018. Metode penelitian kuantitatif, kualitatif dan R\&D. Bandung: Alfabeta.

Teo, T. \& Liu, J., 2007. Consumer trust in e-commerce in the United States, Singapore and China. Omega, Volume 35 , pp. 22-38.

Venkatesh, V. \& Davis, F., 1996. A model of the antecedents of perceived ease of use: development and test. Decision Sciences, 27(3), pp. 451-481.

Venkatesh, V., Morris, M. \& Ackerman, P., 2000. A longitudinal field investigation of gender differences in individual technology adoption decision-making process. Organizational Behavior and Human Decision Processes, 83(1), pp. 33-60.

Venkatesh, V., Thong, J. \& Xu, X., 2012. Consumer acceptance and use of information technology: Extending the unified theory of acceptance and use of technology. MIS Quarterly, Volume 36, pp. 157-178.

Wang, L., Luo, X., Yang, X. \& Oiao, Z., 2019. Easy come or easy go? Empirical evidence in switching behaviors in mobile payment applications. Information \& Management, 56(7).

Wijanto, S., 2008. Structural equation modeling dengan Lisrel. Yogyakarta: Graha Ilmu.

Yang, Y., Liu, Y., Li, H. \& Yu, B., 2015. Understanding perceived risks in mobile payment acceptance. Industrial Management \& Data Systems, 115(2), pp. 253-269.

Zhou, T., 2011. The effect of initial trust on user adoption of mobile payment. Information Development, Volume 27, pp. 290-300.

Zhou, Z., Jin, X.-L. \& Fang, Y., 2014. Moderating role of gender in the relationships between perceived benefits and satisfation in social virtual world continuance. Decision Support Systems, Volume 65, pp. 69-79. 